\title{
Correction to: Genome-wide Identification of Trihelix Genes in Moso Bamboo (Phyllostachys edulis) and Their Expression in Response to Abiotic Stress
}

\author{
Hongyan Gao ${ }^{1} \cdot$ Rong Huang ${ }^{1} \cdot$ Jun $\mathrm{Liu}^{1} \cdot \mathrm{Zhimin} \mathrm{Gao}^{1} \cdot$ Hansheng Zhao ${ }^{1}$ Xueping $\mathrm{Li}^{1}$
}

Published online: 1 April 2019

(c) Springer Science+Business Media, LLC, part of Springer Nature 2019

\section{Correction to: Journal of Plant Growth Regulation https://doi.org/10.1007/s00344-019-09918-9}

The original version of this article unfortunately contained an error in Funding section. The authors would like to correct the error with this erratum.

Funding National Key R\&D Program of China (Funding number: 2018YFD060010202) supported this study.

Publisher's Note Springer Nature remains neutral with regard to jurisdictional claims in published maps and institutional affiliations.

The original article can be found online at https://doi.org/10.1007/ s00344-019-09918-9.

\section{Xueping Li}

lxp@icbr.ac.cn

1 International Center for Bamboo and Rattan, Key Laboratory of Bamboo and Rattan Science and Technology,

National Forestry and Grassland Administration, No. 8,

Wangjing Futong East Street, Chaoyang District, Beijing,

People's Republic of China 